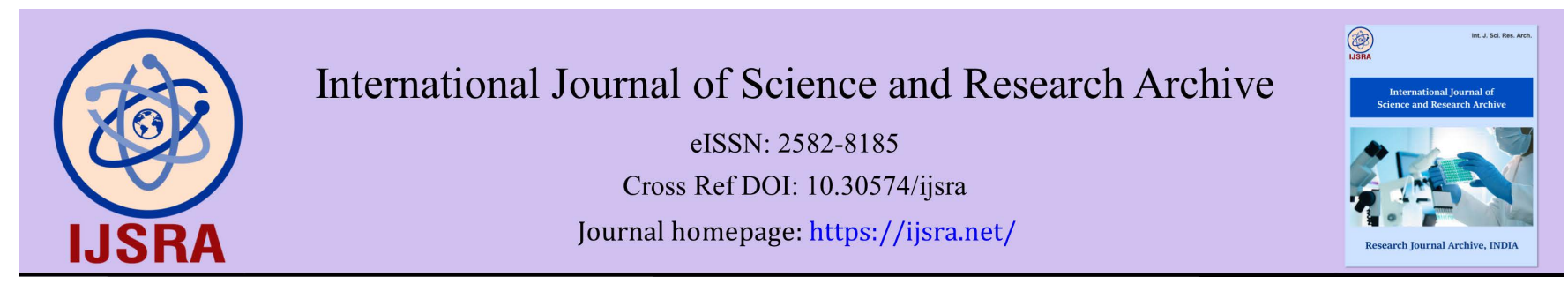

(REVIEW ARTICLE)

\title{
Hippotherapy in multiple Sclerosis: A review focusing on motor function
}

Konstantinos Moutaftsis 1, Evgenia Trevlaki 1, *, Anna Chalkia 1, Konstantinos Chandolias 2, Emmanouil Trevlakis ${ }^{1}$, Georgios Leptourgos ${ }^{1}$ and Nikitas Papazoglou ${ }^{1}$

${ }^{1}$ Department of Physical Therapy, International Hellenic University, Greece.

2 Physiotherapy department, University of Thessaly, Greece.

International Journal of Science and Research Archive, 2021, 04(01), 106-114

Publication history: Received on 18 October 2021; revised on 28 November 2021; accepted on 30 November 2021

Article DOI: https://doi.org/10.30574/ijsra.2021.4.1.0185

\begin{abstract}
Hippotherapy is used in physiotherapy as a treatment that takes advantage of the unique characteristics of the horses' walk impulses and triggers movement responses in patients sitting on the horse's back. The research evidence for application of hippotherapy at people with neurological deficits and disabilities is sparse. Multiple sclerosis (MS) is a chronic and inflammatory disease that affects the neurons of the Central Nervous System. The aim of this review article was to presents the effect of hippotherapy at people with MS. PubMed, Science Direct, Pedro, Total and National Institute Hi.K.E.R., and Google Scholar were searched from 2005 to 2021. Out of 271 studies, 14 were included. The results showed that hippotherapy has a positive impact on the motor function, the walking cycle, the endurance, the balance, and the orthostatic control of people with MS. Further research must be done in a greater scale and investigate the way hippotherapy affects the quality of life, the self-confidence and the social inclusion of people with MS. In summary, the application of hippotherapy in people with MS contributes positively to the progression of the disease and enhances the functionality of individuals.
\end{abstract}

Keywords: Multiple sclerosis; Hippotherapy; Balance; Walking cycle; Quality of life

\section{Introduction}

\subsection{Multiple Sclerosis}

Multiple sclerosis (MS) is a chronic, inflammatory disease that affects the neurons of the Central Neuron System (CNS) [1]. MS is estimated that affect 30-80 cases per 100,000 people [2]. In the U.S. about 400,000 people suffer from this disease. It is one of the most common causes of neurological disability that mainly affects ages 20 to 50 years old, with average age of establishment being 32 years [2]. MS is two to three times more common in women than in men. Populations such as Alaska's indigenous Inuit, Norway's Lapons, Australia's Avorines and New Zealand's Maori almost never show MS. Smoking and low vitamin D levels are associated with an increased risk of MS [1]. According to epidemiological studies smokers have a 40-80\% greater risk of developing MS [1] and are more than three times more likely to experience a transition of recurrent MS to a secondary prolapse, compared to non-smokers.

\subsection{Pathophysiology}

The exact causes of MS are still unknown, but exposure to environmental factors, particularly viruses, is thought to trigger MS in people with general predisposition [1]. Incriminating agents can be various viruses, such as herpes virus 6 (HHV-6), human T-lymphotropic virus 1 (HTLV-1) and Epstein-Barr virus [1].

\footnotetext{
* Corresponding author: Evgenia Trevlaki

Department of Physical Therapy, International Hellenic University, Greece.

Copyright (c) 2021 Author(s) retain the copyright of this article. This article is published under the terms of the Creative Commons Attribution Liscense 4.0.
} 
MS is a demi-myelinating disease of the CNS [2]. This occurs as the damage results from the presence of areas with special demyelination, where they are scattered in the white substance and the parenchyma of the CNS. Specifically, the loss of myelin and fatty substance, which acts as insulation for the nerves, dramatically slows down or blocks the transmission of nerve impulses, resulting in specific symptoms to the affected neurons of CNS [2]. The restriction of inflammation and accompanying edema, with compensatory remyelination by oligodendrocytes and neuroaxial plasticity, is considered to be responsible for the remission of symptoms [2]. The loss of myelin affects the coordination of movements, the good preservation of aesthetic receptors, but also the speed of inflow and outflow of stimuli.

According to Charcot the clinical and histopathological characteristics of the disease, that became known as the Charcot triad, are Intention tremor, sleepy and telegraphic speech [3]. MS can affect various parts of the CNS, such as the cerebral hemispheres, brain stem, cerebellum, spinal cord and optic nerves [4].

While there is no way to predict with any certainty the way an individual's disease will progress, four basic MS disease courses have been defined by the International Advisory Committee on Clinical Trials of MS in 2013: clinically isolated syndrome, relapsing remitting, secondary progressive and primary progressive [5].

Table 1 Symptoms of Multiple Sclerosis

\begin{tabular}{|l|l|}
\hline Aesthetic Symptoms & Hypoesthesia, Hemodes, Hallucinations \\
\hline Pain & Dysesthesias, Chronic pain, Optic neuritis \\
\hline Visual Symptoms & Blurred Vision, Kills, Sleepy \\
\hline Kinetic Symptoms & Fatigue, Ataxia, Terror, Spasticity \\
\hline Cognitive Symptoms & Reduced Information Processing Speed, Visual Processing Disorder \\
\hline Emotional / Behavioral & Depression, Euphoria, Adjustment Problems \\
\hline Cardiovascular Dysautonomy & Nocturia, Diarrhea, Incontinence, Constipation \\
\hline Cardiovascular Dysautonomy & Reduced vaginal lubrication, Decreased erotic desire, Erectile dysfunction \\
\hline
\end{tabular}

\subsection{Hippotherapy}

The application of hippotherapy for people with neurological deficits (MS, cerebral palsy) and motor disabilities is another powerful physiotherapeutic approach [6]. In hippotherapy the main therapeutic resource is the horse in an interactive and multifactorial environment. Balls, powders, sounds are used in the treatment, in order to strength the sensory and motor centers of the person with MS [6].

In hippotherapy interventions the patient is on the back of the horse in position either towards the head of the horse or towards the rear side [6]. The program must be pleasant, motivated, and flexible towards the patient, strengthening his emotional background (confidence, joy, will). The method aims to improve balance, increase the mobility of the pelvis (recovery-break), reduce falls, stiffness, and spasticity, improve the gait, self-confidence of the individual, and finally activate the mobility of individual's members [7]. For that reason, a detailed assessment of the patient must be carried out at a cognitive, musculoskeletal, and neurological level [6].

Hippotherapy differs from classical physiotherapy mainly in the treatment area (the equestrian group) and the main mean of therapy (the horse) [7]. According to the American Quarter Horse Association (AQHA), hippotherapy refers to the way physiotherapists use their clinical and practical reasoning in combination with the use of equidae and horse movement [7]. Hippotherapy is considered to be a complete plan of patient care.

Hippotherapy is a new therapeutic approach that has yet to be analyzed in depth from the physical therapy point of view. This review aims to address this by examining the effect of hippotherapy in patients with MS, as far as fatigue, balance, torso control, gait and quality of life is concerned. Increased research effort is required from the physical therapy community to identify the effects of hippotherapy in MS efficiently.

\section{Material and methods}

The search was conducted to investigate the effectiveness of hippotherapy in MS. The protocol of this systematic review was developed and has been registered in the International Prospective Register of Systematic Reviews (PROSPERO 
CRD42021258882). PubMed, Science Direct, Pedro, Google Scholar, Total and National Institute Hi.K.E.R. were searched. The main term used were 'Hippotherapy in Multiple Sclerosis'. The exclusion criteria were case studies and the publication date (2005-2021). The articles that finally met all the criteria and were analyzed, after the removal of the copies, the reading of the title, the summary or even the whole text, were 14.

\section{Results}

Firstly, the search results were studied at the title and abstract level. Those studies that were not rejected were secured and their full text was examined in order to collect those studies that met the inclusion criteria for the review. Finally, 14 articles were published which refer to the effectiveness of hippotherapy applied in the treatment of MS and are mentioned in detail in Table 2.

Table 2 Summary of studies that used hippotherapy as a therapeutic approach in people with Multiple Sclerosis

\begin{tabular}{|c|c|c|c|}
\hline Researchers & Subjects & Intervention & Assessment \\
\hline $\begin{array}{l}\text { Silkwood- } \\
\text { Sherer D et } \\
\text { all., } 2007\end{array}$ & $\begin{array}{l}\mathrm{N}=15 \text { (6 males, } 9 \\
\text { females) individuals } \\
\text { with MS }\end{array}$ & $\begin{array}{l}9 \text { individuals ( } 4 \text { males, } 5 \text { females }) \\
\text { received weekly HT for } 14 \text { weeks. The } \\
\text { other } 6 \text { individuals }(2 \text { males, } 4 \\
\text { females) were a comparison group }\end{array}$ & $\begin{array}{l}\text { BBS and POMA at } 0.7 \text { and } 14 \\
\text { weeks }\end{array}$ \\
\hline $\begin{array}{l}\text { Frevel } \quad \text { D, } \\
\text { Mäurer } \\
2014\end{array}$ & $\begin{array}{l}\mathrm{N}=18 \text { patients with } \\
\text { MS (EDSS) 3.5) took } \\
\text { part in the trial. e- } \\
\text { Training }(\mathrm{n}=9) \text { was } \\
\text { compared with the } \\
\text { outcome of patients } \\
\text { receiving HT }(\mathrm{n}=9)\end{array}$ & $\begin{array}{l}\text { Randomly allocated patients received } \\
\text { HT or internet-based home training }\end{array}$ & $\begin{array}{l}\text { The evaluations were carried } \\
\text { out before and after the } \\
\text { intervention and included a } \\
\text { static and dynamic of balance }\end{array}$ \\
\hline $\begin{array}{l}\text { Schatz L, et } \\
\text { al., } 2014\end{array}$ & $\begin{array}{l}\mathrm{N}=29, \text { aged } \geq 18 \\
\text { years with clear MS } \\
\text { with reduced } \\
\text { walking capacity } \\
\text { (EDSS } 4.0 \text { to } 7.0 \text { ) }\end{array}$ & $\begin{array}{l}\text { HT group ( } 15 \text { patients, } 10 \text { women, } 5 \\
\text { men, aged } 45.2+/-8.5 \text { years, median } \\
\text { EDSS 5.0), received } 1 \text { week, } 20 \\
\text { minutes of HT. Control group (CG, } 14 \\
\text { patients, } 11 \text { women, } 3 \text { men, aged } 48.6 \\
+/-9.6 \text { years, median EDSS } 5.0) 1 \\
\text { week with an additional } 30 \text { minutes of } \\
\text { simple physiotherapy session }\end{array}$ & 6minWT, 10Mwt and TGUG \\
\hline $\begin{array}{l}\text { Vermöhlen } \\
\text { V, et al., } 2018\end{array}$ & $\begin{array}{l}\mathrm{N}=70 \text { adults with } \\
\text { MS from } 5 \text { German } \\
\text { centers, random } \\
\text { distribution }\end{array}$ & $\begin{array}{l}\text { HT group, conventional therapy, and } \\
12 \text { weeks of HT. Control group } \\
\text { underwent only the conventional } \\
\text { therapy }\end{array}$ & BBS after 12 weeks \\
\hline $\begin{array}{l}\text { Lindroth } \\
\text { JL,et al., } 2015\end{array}$ & $\begin{array}{l}\mathrm{N}=3 \text { (two women } \\
\text { and one male, age } \\
\text { range } 37-60 \text { years) } \\
\text { with diagnoses of } \\
\text { relapse } \\
\text { progressive MS }\end{array}$ & $\begin{array}{l}\text { The intervention was physical } \\
\text { therapy using HT (HPOT) twice } \\
\text { weekly for } 6 \text { weeks with assessments } \\
\text { prior, directly after, and } 6 \text { weeks after } \\
\text { discharge }\end{array}$ & SOT test, BBS and FGA \\
\hline $\begin{array}{l}\text { Salehi } \\
2019\end{array}$ & $\begin{array}{l}\mathrm{N}=24 \text { patients with } \\
\text { MS from a clinical } \\
\text { center in Isfahan } \\
\text { were recruited } \\
\text { through } \\
\text { appropriate } \\
\text { sampling and } \\
\text { randomly in } \\
\text { experimental and } \\
\text { control groups. }\end{array}$ & $\begin{array}{l}\text { The experimental group followed } \\
\text { psychological support while the post- } \\
\text { emsis control group underwent HT } \\
\text { training for } 8 \text { weeks ( } 3 \text { days in a week } \\
\text { for } 30 \text { minutes) }\end{array}$ & $\begin{array}{l}\text { Hamburg's fear of the quality of } \\
\text { life tool of hardening, 54- } \\
\text { MSQOL, Scale of physical } \\
\text { disability, } \quad \text { Shapiro-Wilk } \\
\text { statistical test and Shapiro-Wilk } \\
\text { statistical test }\end{array}$ \\
\hline
\end{tabular}




\begin{tabular}{|c|c|c|c|}
\hline $\begin{array}{l}\text { Ivanova I, } \\
2020\end{array}$ & $\begin{array}{l}\mathrm{N}=40 \text { participants - } \\
18 \text { men and } 22 \\
\text { women - clinically } \\
\text { diagnosed with } \\
\text { recurrent- } \\
\text { intermittent MS }\end{array}$ & $\begin{array}{l}\text { The therapy group underwent } 10 \\
\text { weeks of physiotherapy, after which } \\
\text { continued with the } 16 \text { sessions of HT, } \\
\text { while control group consisted of } \\
\text { women underwent proprioceptive } \\
\text { PNF, MFT, AT, HT }\end{array}$ & $\begin{array}{l}\text { There were three tests: at the } \\
\text { beginning, in the middle and } \\
\text { after the last class. BBS, } \\
\text { Emotional Intensity Test, Pain } \\
\text { Impact, Chronic Fatigue Test, } \\
\text { Bertotti scale }\end{array}$ \\
\hline $\begin{array}{l}\text { Thompson F, } \\
2014\end{array}$ & $\begin{array}{l}\mathrm{N}=8 \text { children with } \\
\text { MS between } 2-12 \\
\text { years of age }\end{array}$ & $\begin{array}{l}\text { The participants completed } 8-12 \\
\text { weeks of HT sessions in Bethlehem, } \\
\text { North Carolina at the Foothills } \\
\text { Equestrian Center. Subjects were } \\
\text { tested before, during, and at the } \\
\text { completion of therapy }\end{array}$ & $\begin{array}{l}\text { A timed level and unlevel } \\
\text { walking test, a coordination- } \\
\text { based reach test, and were } \\
\text { scored using the (G.R.E.A.T.) } \\
\text { Orthostatic scale and } \\
\text { Psychological changes were } \\
\text { also assessed based on } \\
\text { physiotherapists' notes and } \\
\text { parents' questionnaires. }\end{array}$ \\
\hline $\begin{array}{l}\text { Dziubek A et } \\
\text { al., } 2021\end{array}$ & $\begin{array}{l}\mathrm{N}=92 \text { patients with } \\
\text { MS, aged } \quad 15-81 \\
\text { years } \quad(85.9 \% \\
\text { women), average } \\
\text { age } 41.78( \pm 15.02) \\
\text { years }\end{array}$ & $\begin{array}{l}46 \% \text { of the patients used } \mathrm{HT} \text {, the rest } \\
\text { followed simple exercises }\end{array}$ & $\begin{array}{l}\text { The NEO-FFI Personality } \\
\text { Inventory has been used for the } \\
\text { study of personality traits } \\
\text { assessment scales }\end{array}$ \\
\hline $\begin{array}{l}\text { Muñoz-Lasa } \\
\text { S et al., } 2019\end{array}$ & $\begin{array}{l}\mathrm{N}=10 \text { patients with } \\
\text { MS. HT group }(\mathrm{n}=6), \\
36-46 \text { years old. } \\
\text { Control group }(\mathrm{n}=4) \\
\text { not randomized and } \\
46-52 \text { years old }\end{array}$ & $\begin{array}{l}\text { The treatment group underwent HT } \\
\text { operations over a period of } 6 \text { months, } \\
\text { the control group was not } \\
\text { randomized, followed by the same HT }\end{array}$ & $\begin{array}{l}\text { MAS, FIS, KHQ life scale and } \\
\text { MSQOL-54 }\end{array}$ \\
\hline $\begin{array}{l}\text { Bronson C, et } \\
\text { al., } 2010\end{array}$ & $\begin{array}{l}\mathrm{N}=20 \text { patients of } \\
\text { MS, aged } 20-35 \\
\text { years old }\end{array}$ & $\begin{array}{l}\text { Group A performed conventional } \\
\text { therapy, while group B performed } \\
\text { conventional therapy together with } \\
\text { HT over } 16 \text { weeks }\end{array}$ & $\begin{array}{l}\text { Patients were evaluated using } \\
\text { the functional the Fugl-Meyer } \\
\text { scale, the BBS, TUG and the FGA }\end{array}$ \\
\hline $\begin{array}{l}\text { Moraes AG et } \\
\text { al., } 2020\end{array}$ & $\begin{array}{l}\mathrm{N}=33 \text { patients with } \\
\text { MS. HT intervention } \\
\text { group } 45.5 \pm 9.7(\mathrm{n}= \\
\text { 17) and control } \\
\text { group } 44.8 \pm 8.8(\mathrm{n}= \\
\text { 16) }\end{array}$ & $\begin{array}{l}\text { The intervention included } 1630- \\
\text { minute HT sessions performed } \\
\text { 2/week. The control group followed } \\
\text { all scales without HT }\end{array}$ & $\begin{array}{l}\text { T25FW, 6MWT and spatial-time } \\
\text { gait assessment using the } \\
\text { GaitRite system. The data was } \\
\text { collected using a mixed model } \\
\text { analysis of variance ANOVA } \\
\text { model with Bonferroni post hoc }\end{array}$ \\
\hline $\begin{array}{l}\text { Hammer, } \\
\text { Ann et al., } \\
2005\end{array}$ & $\begin{array}{l}\mathrm{N}=11 \text { MS patients. } \\
\text { Mean age } 47.9 \text { years } \\
\text { old (SD 8.4, range } \\
3561 \text { years). Years } \\
\text { since diagnosis } \\
\text { (mean 10, median } 7 \\
\text { years) }\end{array}$ & $\begin{array}{l}\text { The intervention included } 10 \text { weekly } \\
\text { HT sessions lasting } 30 \text { minutes each }\end{array}$ & $\begin{array}{l}\text { BBS, MAS, MFI, Birgitta } \\
\text { Lindmark engine rating, VAS for } \\
\text { pain, the scale SRLMT, } \\
\text { functional scale for the patient } \\
\text { for ADL and the SF-36 }\end{array}$ \\
\hline $\begin{array}{l}\text { Muñoz-Lasa } \\
\text { S, et al., } 2011\end{array}$ & $\begin{array}{l}\mathrm{N}=27 \text { patients with } \\
\mathrm{MS}, 18-60 \text { years old }\end{array}$ & $\begin{array}{l}\text { Patients were divided into two } \\
\text { groups: } 12 \text { underwent THR and } 15 \\
\text { traditional physiotherapy }\end{array}$ & $\begin{array}{l}\text { EDSS, 6MWT, 10MWT, TGUG, } \\
\text { Barthel Index and POMA }\end{array}$ \\
\hline
\end{tabular}

HT= Hippotherapy, BBS=Berg Balance Scale, ROM= Range of motion, MS= Multiple Sclerosis, HRQOL = Health-Related Quality of Life , ADL= Activities of Daily Living , TUG = Time Up and Go , G.R.E.A.T = Gainesville Riding through Equine Assisted Therapy , TR= therapeutic riding , HT= Hippotherapy , MS= Multiple Sclerosis, EDSS= Extended Disability Status Scale, POMA= Performance-Oriented Mobility Assessment, T25FW = 25foot hiking, 6MWT= 6-minute walk, MAS = Modified Ashworth scale, FIS=Fatigue Impact Scale, KHQ= King's Health Questionnaire, MSQOL-54 = Multiple Sclerosis Quality of Life , PNF = proprioceptive neuromuscular facilitation MFT= myophastic techniques, AT =autonatal training, HPOT= hippotherapy, SOT =Sensory Organization Test, FGA= functional gait assessment, VAS= Visual Analogue Scale. 


\subsection{Fatigue}

The spasticity and fatigue through horse therapy were studied by S. Muñoz-Lasa et al. [8] in 2019. The sample divided in a non-randomized therapy group, 6 months of hippotherapy in patients with MS ( $n=6)$, and non-randomized control group $(n=4)$. The results showed statistically significant improvement in fatigue impact $(p<, 0001)$ measured with FIS. The perception of the outcome in the urine quality of the KHQ life scale $(p=.033)$ and in subcategories 2, 3 and 4 of MSQOL-54 ( $\mathrm{p}=.011)$. The results of the control group showed no positive increase in the scale.

In 2020 Inna Ivanova [9] conducted a study on fatigue in MS. The strong correlation between these indicators $(\mathrm{r}=-$ 0.788 ) was found to be $62.9 \%$ ( $\mathrm{a} \leq 0.01$ ). In the post-experiment measurements, the relationship increased $(\mathrm{r}=-0.798$, $63.68 \%$ significance level, to a $\leq 0.01$ ), which means that the increase in fitness, expressed by the decrease in chronic fatigue values. The correlation between the indicators "fatigue" and "emotional tension" remains moderate $(r=0.343$, at the end $r=0.341$ ), which shows that in men these two indicators have no significant impact on each other. The correlation of "balance" and "emotional intensity" was moderate ( $r=-0.349)$, with a low level of $12 \%$ importance, and in the end the values increased significantly to a level of $27.87 \%(a \leq 0.05)$.

\subsection{Balance}

The overall approach of balance, gait, coordination, and emotion were examined by A. Hammer et al. [10] in 2005. The intervention included 10 weekly therapeutic riding (TR) / hippotherapy (HT) sessions lasting 30 minutes each. Individuals were measured no more 13 times, four times weekly through phase A1 (pre-intervention), four to five through phase B (intervention) and three to four through phase A2 (post-intervention). The results showed improvement in four of thirteen subjects from phase A1 to B and in five subjects from phase A1 to A2, balance was observed in eight subjects, three subjects improved in SRLMT. As far as ADK score is concerned four people rated an improvement. HRQOL reported twenty-eight positive and sixteen negative scores. The results reported slightly more changes in mental twenty-four individuals than in physical twenty individuals observed dimensions. In five subjects, both positive and negative changes had occurred within the same individual. Only five reported a positive direction change, thus in one subject only a negative direction. In general, for the ADL and HRQOL scores, nine people showed improvement, mainly in one variable each.

Balance after hippotherapy interventions was studied by C. Bronson et al. [11] in 2010. According to the results, a significant difference was reported between the final group BBS scores (Hippotherapy group: median= 55.0, Control Group median $=41.0$ ). During the intervention three of eleven patients had an increasing trajectory in balance and five patients had long-term improvement in balance. Only one patient's balance deteriorated overall. According to TUG two patients had an increasing course in the results.

D. Frevel et al. [12] studied the dynamic and static ability. Both intervention groups, e-Training group and Hippotherapy group, showed a comparable and extremely significant improvement. The e-Training group reported significantly higher values compared to the original DGI $(\mathrm{p}=.016)$ and BBS $(\mathrm{p}=.011)$ in balance capacity. The hippotherapy group also showed significant improvement in dynamic DGI ( $p=.011)$ and static balance BBS ( $p=.011)$ after 12 weeks. According to the muscle strength measurements participants in both groups showed on average higher non-significant strength values of $p>0.05$ in the measurement of isometric strength of the foot and torso after intervention. The results of the 2MWT showed significantly higher value ( $p=.032)$ only in the first minute in the hippotherapy group. The eTraining group reported a significantly lower value $(\mathrm{p}=.031)$ only in the cognitive subscale of MFIS of fatigue. There was a significant difference between the intervention groups in the cognitive subscale of MFIS ( $p=.012)$. The hippotherapy group noted significantly lower values of high quality of life in the subscales of cognitive function $(p=.026)$ of the lower extremity ( $p=.008)$ and the mood ( $p=.045)$ compared to the baseline, while there was no significant improvement in the e-Training group. The intervention groups differed significantly in the subscale function of the upper extremity ( $\mathrm{p}=.037)$.

Torso and balance were examined by D. Silkwood-Sherer et al. [13] study, in which the team receiving hippotherapy showed a statistically significant improvement from pretest ( 0 week) to posttest (14 weeks) for BBS [average increase of 9.15 points $(\mathrm{x}(2)=8.82, \mathrm{p}=.012)$ ] and POMA results [average increase $5.13(\mathrm{x}(2)=10.38, \mathrm{p}=.006)]$. The comparison group had no significant changes in BBS [average increase of $0.73(\mathrm{x}(2)=0.40, \mathrm{p}=.819)$ ] or POMA [average decrease of $0.13(\mathrm{x}(2)=1.41, \mathrm{p}=0.494)]$. A statistically significant difference was also found between the final BBS scores of the groups (median treatment group $=55.0$, median comparison group value 41.0, $\mathrm{U}=7, \mathrm{r}=-0.49$ ).

In 2014, Mr. Thompson et al. [14] conducted a study on torso and orthostatic control. The results showed that $62.5 \%$ (5/8) of individuals improved in the Orthostatic Scale score, $87.5 \%(7 / 8)$ reduced their time to complete the level and non-flat distances, and 50\% (4/8) of participants showed better range results based on post-coordination. One relevant 
samples Wilcoxon signed rank test showed statistically significant improvements in posture before post-body position $(\mathrm{p}<.05)$, and a relative Wilcoxon classification test showed significant decreases in timed walking from the traitorous test $(\mathrm{p}<.05)$.

\subsection{Gait - Walk cycle}

AG. Moraes et al. [15] in 2020 conducted a study that showed improvement in walking performance after hippotherapy in patients with MS. The participants were separated in two groups, hippotherapy group $(\mathrm{n}=17)$ and control group $(\mathrm{n}$ = 16). The intervention included 16 horse therapy sessions of 30-minute performed twice a week. The effects of an 8week hippotherapy intervention on walking performance and spatial-time gait parameters were evaluated. Compared with control, the intervention group significantly increased 6MWT distance $(+9.70 \%, \mathrm{p}<.001)$ and decreased T25FW time $(-15.86 \%, \mathrm{p}<.001)$. According to spatiotemporal gait parameters, the intervention group experienced significantly higher improvements in most variables ( $\Delta \%$ from 3.66 and $41.43 \%$, all $\mathrm{p}<0.005)$ from the control group. Only balance time $(\mathrm{p}=.043)$, stance time $(\mathrm{p}=.031)$, and absolute $(\mathrm{p}=.004)$ and relative $(\mathrm{p}=0.017)$ double support time were identified as significant mediators of the effects of hippotherapy on walking performance evaluated by T25FW. There was no notable mediator for 6MWT (all p >.05)

The walking cycle was examined by S. Muñoz-Lasa et al. [16] study. A total of twenty-seven people with MS participated and were divided into two groups: 12 underwent Therapy horse riding (THR) and 15 traditional physiotherapy, for both groups two series of 10 weekly sessions were held. The results showed a significant improvement in POMA scores $(\mathrm{p}<0.005)$, whereas EDSS and Barthel index did not significantly change. The hippotherapy group significantly reduced its stride time $(\mathrm{p}<0.04)$, whereas gait speed and cadence showed a (not statistically significant) trend to increase. Similarly, ground reaction forces significantly increased $(p<0.01)$ in the therapy group. At Global Rating of Change Scale, 9 out of 12 patients of the THR group declared an 'at least slight improvement' $(>+1)$, whereas only 3 out of the 14 patients of the conventional therapy group stated they had slightly improved (+1). In general, no statistically significant change was found in the control group.

Schatz L. et al. [17] studied the contribution of hippotherapy to the walking cycle. The results showed that 6MWT was improved significantly after 3 weeks in both hippotherapy and control groups. The gait analysis was significantly different only in hippotherapy group. Only the hippotherapy group had positive results immediately after intervention and significant improvements in 6minWT, 10mWT and TGUG from Tuesday to Wednesday, while the control group showed no differences. The results reported that the age of 18-60 years old was diagnosed with reduced walking ability Expanded Disability Status Scale (EDSS) $4.0-7.0$.

Sensory information and walking were studied by JL Lindroth et al. [18] in 2015. The hippotherapy participants, after the intervention period, reported improvements in the SOT scores (range 1-8 points), BBS (range 2-6 points) and FGA (average 4 points) in all three participants. These improvements were maintained or continued to improve during the follow-up evaluation. Two of the three participants no longer relied at the same level on vision and/or somatosensory information, as the main sensory input for orthostatic control suggested improved use of sensory information for balance. Assessments were completed 1 week prior to the start of intervention (T0), within 1-week post-intervention (T1), and after a follow-up period of 6 weeks (T2). Participant's 1 SOT composite score improved from 58 (T0) to 59 (T1), and up to 63 (T2). The SOT analysis showed that participant 1 had an increased dependence on somatosensitive input during pre-testing with difficulty in using optics and vestibly system. A continuous improvement was reported in BBS, from a pre-test score of 41, up to 46 in T2. FGA scores improved from a pre-test score of 12 to a post-test score of 16, with a further one-point increase in T2. Participant 2 increased sensory information and walking from 76-84 (T0) at week 6 to a small change of 78 (T2) in SOT score. Participant 2 used appropriate environmental sensory indications during pre-testing, improved the use of the input chamber after hippotherapy intervention. BBS results improved to 46 after 6 weeks of hippotherapy intervention and continued to improve to 48 with the T2 assessment. Participant's 3 SOT score was steadily improved from 71 (T0) to normal range 81 (T2). Based on the results of organoleptic analysis of the SOT participant 3 was improved by an initial dependence on visual indications during the pre-test assessment using sensory indications during the test and the T2 evaluation. The BBS scores improved post-intervention and the T2 rating was above his pre-test score of 46 .

\subsection{Quality of life}

The improvement of the quality of life at women with MS through horse therapy was studied by M. Salehi et al. [19] in 2019. A significant difference between the intermediate results of the experimental groups and the control groups was observed in mental health dimensions of quality of life. The results showed that horse therapy training has a positive effect on the quality of life of women with multiple MS. According to the results the alpha factor of Cronbach had a 
significant difference in most women ( $\mathrm{p}>.001)$. Between pre-tests and after testing, the control group also had a significant difference ( $\mathrm{p}>.05)$.

In 2021 A. Dziubek et al. [20] studied 92 patients with MS, aged 15-81 years (85.9\% women), average age of 41.78 years ( \pm 15.02$)$, who used hippotherapy as a method of rehabilitation. The NEO-FFI personality stock has been used to study personality traits. Clinical data and information on hippotherapy were collected by the improvised study. The characteristic most strongly expressed in all patients was consciousness $(31 \pm 7.51)$ and the least pronounced trait was neuroticism $(24 \pm 10.42)$. Hippotherapy were used by $46 \%$ of the participants and, compared to non-users had a significantly higher level of agreement ( 34 v. 29, p <.001) and consciousness (33 v. 29, p =.009). Hippotherapy was used more often by elderly patients (mean age $49 \pm 13.7$ years), while the mean age of non-users was $36 \pm 13.6$ years (p $<.001)$. Gender, education, place of residence and financial situation did not influence the choice of hippotherapy as a method of rehabilitation.

Seventy adults suffering from MS from five German centers were studied by V. Vermöhlen et al. [21] in 2018. The sample were randomly divided into the intervention group (12 weeks of hippotherapy) and the control group. The evaluation included the primary result by the BBS after 12 weeks and the further outcome measures, that examined fatigue, pain, quality of life and spasticity. The co-change analysis of the primary endpoint led to an average difference in the $2.33 \mathrm{BBS}$ change (95\% confidence interval (CI): 0.03-4.63, $\mathrm{p}=.047$ ) between intervention $(\mathrm{n}=32)$ and control group ( $\mathrm{n}=38$ ). The benefit in BBS was the biggest for the Expanded Disability Status Scale (EDSS) subgroup $\geqslant 5$ (5.1, p =.001). Fatigue $(-6.8, p=0.02)$ and spasticity $(-0.9, p=0.03)$ were improved in the intervention group. The average change difference between the groups was $12.0(\mathrm{p}<.001)$ in the physical health score and $14.4(\mathrm{p}<.001)$ in the mental health score of MS Quality of Life-54 (MSQoL-54).

\section{Discussion}

The effectiveness of Hippotherapy for the treatment of patients with MS has now been demonstrated through various studies. The parameters examined was fatigue, balance, gait, and quality of life.

As far as fatigue is concerned S. Muñoz-Lasa et al. [8, 16], Inna Ivanova et al. [9] and Vermöhlen et al. [21] found a strong positive correlation between fatigue and hippotherapy. Specifically, in Inna Ivanova et al. study that correlation was up to $62.9 \%$ which means that the increase in fitness results in the decrease in chronic fatigue values.

According to the finding, hippotherapy appeared to have a positive impact on balance. In more details, Hammer et al. [10], C. Bronson et al. [11], Frevel et al. [12], Lindroth et.al. [18], D. Silkwood-Sherer et al. [13], Mr. Thompson et al. [14] and Inna Ivanova et al. [9] studies presented a significant improve in balance. Most of the studies used BBS as an evaluating tool. In Inna Ivanova et al. [9] study the correlation between hippotherapy and balance was found to be $12 \%$, while in Mr. Thompson et al. [14] study the coordination was improved in $50 \%$ of the participants and indicated a positive impact on the pediatric population for function and quality of life.

Regarding the Moraes et al. [15], Muñoz-Lasa et al. [16], Schatz et al. [17] and Lindroth et al. [18] studies, gait and walking cycle was significantly improved. All the above studies showed notable improvement in the walking performance. Furthermore, Moraes et al. [15] and Schatz et al. [17] study presented statistically significant improvement in 6MWT, 10MWT and T25FW. The Muñoz-Lasa et al. [16] study showed improvement in two walking parameters: stride time $(\mathrm{p}<.04)$ and ground reaction forces $(\mathrm{p}<.01)$ in the therapy group.

According to the findings, Muñoz-Lasa et al. [8,16], Salehi et al. [19], Dzinbek et al. [20] and Vermöhlen et al. [21] studies showed improvement in the quality of life of the patients. Moreover, Salehi et al. [19] study presented a significant improvement in alpha factor of Cronbach in women ( $p$ >.001). In Dzinbek et al. [20] study the least pronounced trait was neuroticism (24 \pm 10.42$)$, while a significantly higher level of agreement (34 v. $29, \mathrm{p}<.001)$ and consciousness $(33$ v. $29, \mathrm{p}=.009$ ) was presented.

\section{Conclusion}

The review article discussed hippotherapy as a therapeutic approach in MS. According to the findings, hippotherapy has both short- and medium-term effects on the quality of walking and walking endurance performance of people suffering from MS. Patients with MS showed significant improvement in balance disturbance and good trunk stability. Through the use of a comprehensive hippotherapy program, patients have managed to be functional, thus improving their walking cycle, enabling them to self-serve. An important increase was observed in the quality of life of women suffering 
from MS, through the possibility of socialization again. Hippotherapy improves confidence, self-esteem as observed by therapists and measured by reliable questionnaires.

Future research must be directed to investigate the rate of improvements in larger groups of patients with MS, the training of more therapists in hippotherapy, but also which asthma receptors are often activated through hippotherapy and improve the deficiencies of MS.

\section{Compliance with ethical standards}

\section{Acknowledgments}

The authors would like to acknowledge International Hellenic University for the opportunity to conduct this review.

\section{Disclosure of conflict of interest}

All authors hereby declare that there is no relationship with any party that may present a potential conflict of interest.

\section{References}

[1] Nichols-Larsen D, Kegelmeyer AD, Buford J, Kloos A, Heathcock J, Basso M. Neurological Rehabilitation: Neuroscience and Neuroplasticity in Applied Physiotherapy. Neuroscience and Neuroplasticity in Applied P/T Translation Daphne Bakalidou. Ed:KONSTANTARAS. 2017.

[2] Dustine L, Moore G. ACSM's exercise: chronic diseases and disabilities. Editing by Greek Language Baltopoulos P. Athens. B.C. Paschalidis. 2005.

[3] Mattle H, M Mumenthaler. NEUROLOGY. Publications: Konstantaras. 2019.

[4] Netter F. PATHOLOGY basic principles 2nd edition. Broken Hill Publishers. 2015.

[5] Shumway-Cook A, Woollacott M. Kinetic Control. From research to Clinical Practice. Publications: BC PASHALIDIS. 2012.

[6] Nikolaou I, Veryzos N. Therapeutic horse riding and horse therapy. Introduction to the Hippo KinesioEducational Recovery Approach Hippo Kinesio-Educational Rehabilitation (Hi.K.E.R.) 2015.

[7] Grooms DR, Page SJ, Nichols-Larsen DS, Chaudhari AM, White SE, Onate JA. Neuroplasticity associated with anterior cruciate ligament reconstruction. Journal of orthopaedic \& sports physical therapy. 2017; 47(3): 180189.

[8] Muñoz-Lasa S, de Silanes CL, Atín-Arratibel MÁ, Bravo-Llatas C, Pastor-Jimeno S, Máximo-Bocanegra N. Effects of hippotherapy in multiple sclerosis: pilot study on quality of life, spasticity, gait, pelvic floor, depression and fatigue. Medicina Clínica (English Edition). 2019; 152(2): 55-58.

[9] Ivanova I. Final analysis of the result in man with multiple sclerosis after a physiotherapeutic. Knowledge International Journal. 2020; 38(4): 843-848.

[10] Hammer A, Nilsagård Y, Forsberg A, Pepa H, Skargren E, Öberg B. Evaluation of therapeutic riding (Sweden)/hippotherapy (United States). A single-subject experimental design study replicated in eleven patients with multiple sclerosis. Physiotherapy theory and practice. 2005; 21(1): 51-77.

[11] Bronson, C., Brewerton, K., Ong, J., Palanca, C., \& Sullivan, S. J. Does hippotherapy improve balance in persons with multiple sclerosis: a systematic review. European journal of physical and rehabilitation medicine. 2010; 46(3): 347-353.

[12] Frevel D, Mäurer M. Internet-based home training is capable to improve balance in multiple sclerosis: a randomized controlled trial. European journal of physical and rehabilitation medicine. 2014; 51(1): 23-30.

[13] Silkwood-Sherer D, Warmbier H. Effects of hippotherapy on postural stability, in persons with multiple sclerosis: a pilot study. J Neurol Phys Therapy. 2007 Jun;31(2):77-84.

[14] Thompson F, Ketcham CJ, Hall EE. Hippotherapy in children with developmental delays: Physical function and psychological benefits. Advances in Physical Education. 2014, 4, 60-69. 
[15] Moraes AG, Neri SGR, Motl RW, Tauil CB, von Glehn F, Corrêa ÉC, de David AC. Effect of hippotherapy on walking performance and gait parameters in people with multiple sclerosis. Multiple sclerosis and related disorders. 2020; 43: 102203.

[16] Muñoz-Lasa S, Ferriero G, Valero R, Gomez-Muñiz F, Rabini A, Varela E. Effect of therapeutic horseback riding on balance and gait of people with multiple sclerosis. G Ital Med Lav Ergon. 2011; 33(4):462-7.

[17] Schatz L, Boswell S, Eitel A, Gusowski K, Flachenecker P. Hippotherapie bei multipler sklerose: ergebnisse einer prospektiven, randomisierten, einfach-blinden studie und ubersicht uber die literature., Neurologie und Rehabilitation. 2014; 20(5): 246-252.

[18] Lindroth JL, Sullivan JL, Silkwood-Sherer D. Does hippotherapy effect use of sensory information for balance in people with multiple sclerosis? Physiotherapy theory and practice. 2015; 31(8): 575-581.

[19] Salehi M, Mohammadzadeh H, Rezaei F. The Effect of Hippotherapy on Quality of Life in Women with Multiple Sclerosis. The Neuroscience Journal of Shefaye Khatam. 2019; 8(1): 21-30.

[20] Dziubek A, Brola W, Wilski M, Potemkowski A. Personality of patients with multiple sclerosis and the use of hippotherapy. Multiple sclerosis and related disorders. 2021; 48: 102722.

[21] Vermöhlen V, Schiller P, Schickendantz S, Drache M, Hussack S, Gerber-Grote A, Pöhlau D. Hippotherapy for patients with multiple sclerosis: A multicenter randomized controlled trial (MS-HIPPO). Multiple Sclerosis Journal. 2018; 24(10): 1375-1382. 